Netherlands research

\section{OECD urges more investment}

Waalre, The Netherlands

THE government of the Netherlands should increase its commitments to the quality and the strength of the research and development system. That is the most important of the recommendations by a group of examiners appointed by the Organization of Economic Cooperation and Development (OECD), whose report was published last week.

The document says that spending on civil research and development in the Netherlands has been a static proportion of Gross National Product (GNP) for several years, but that it has been a growing proportion of GNP in Japan, the United States and many other European countries. The OECD examiners say that the government of the Netherlands should seek to redress the balance if it wishes to retain its competitive position in the industrialized world.

The government contribution to research and development has been a declining proportion of the total in recent years, according to the report. Total expenditure on research and development by government and private companies is estimated to amount to 9,000 million guilders in 1986 , or 2.15 per cent of this year's GNP. But while this represents a gradual increase over the 1.96 per cent of GNP spent in 1980, the government's share during this interval has increased from 0.93 per cent to only 0.96 per cent of GNP.

Although the spending of private companies has increased during this period, the OECD examiners point to the wellknown circumstance that most company expenditure on research and development in the Netherlands is accounted for by only five private companies, typified by Shell and Philips, the electronics company. In 1986, it is estimated, these five multinational companies will account for two-thirds of the private company spending of 4,260 million guilders.

According to the OECD report, the Dutch government should be especially concerned to strengthen spending on fundamental research closely linked with new technology. It says that Dutch universities are lagging behind those in other comparable countries. Professor Eugen Seibold, president of the European Science Foundation and one of the examiners, points out that West Germany is spending relatively twice as much as the Netherlands on basic research.

Another examiner, Professor Christopher Freeman of the University of Sussex, urges that funds should not be distributed to universities by means of block grants but only after peer review.

The examiners also plead for more spending on scientific equipment and on facilities such as information systems and libraries. The report suggests that there should be special efforts in the immediate future to make up for past neglect. Acknowledging that the system for the administration of science in the Netherlands is complicated, the examiners say that it is not easy to suggest changes, but agree with the decision made in 1983 that responsibility for technology policy should rest with the ministry of economic affairs.

According to Freeman, one of the advantages of this move is that it will help to educate economists more usually concerned with the question of macro-

\section{Canadian research}

Washington

The Canadian Scientific Research Tax Credit (SRTC) programme, launched in 1983 to encourage investment in industrial research and development, has turned into a financial and political scandal. To a limited extent, the scheme functioned as intended, but it also provided an avenue for get-rich-quick schemes by financial entrepreneurs, and has cost Canadian taxpayers somewhere between $\$ 900$ and $\$ 3,000$ million in lost revenue.

Introduced as part of the 1983 federal budget, SRTC provided a 50 per cent tax credit for investment in research and development. The idea was to make cash available for new companies that would one day provide the backbone of Canada's high technology industry. Since many start-up businesses would not show sufficient profits to benefit from the credits, the government decided to make the credits transferable to other investors able to make use of the tax breaks. Under the arrangements introduced, small research and development companies would get much-needed infusions of cash from the sale of their entitlements while larger investors would save money on taxes. So everybody would be happy, and, in the long run, Canada would get a thriving new industry.

But problems surfaced rapidly. Lenders received tax credits for research in which they had no equity interest and so took little interest in how or whether it was carried out. Because there was no time limit for holding the SRTCs, the credits soon became negotiable financial instruments, and even items for speculation, with brokers making large profits from commissions on their sale.

In one common practice, called the quick flip, a large company or venture capitalist would lend a smaller research

economic growth in the relevance of technology to the question of growth and change. Although the minister of education and science in the Netherlands government will remain responsible for the coordination of technology policy, the involvement of the ministry of economic affairs will ensure that there is increased awareness of the relationship between technology and economic growth.

So much appears to have been recognized by the present cabinet, which has given the issue political priority. But because of the impending elections due on 21 May, and especially because the present coalition may not survive the polls, the ministers of economic affairs and of education and science have been reluctant to comment on the issues raised by OECD.

Casper Schuuring

\title{
Tax incentive scheme goes awry
}

and development company $\$ 5$ million, earning an entitlement to a $\$ 2.5$ million tax credit. The smaller company would then pay back half the loan, plus a brokerage commission of up to 12 per cent. The large company would get all its money back, split between cash and tax credits. The small company would end up with an infusion of $\$ 5$ million in cash, together with an obligation to spend $\$ 5$ million on research. Some companies never even attempted to do the research, but simply made off with the cash. Others tried what is called the double-flip, selling their research obligations to smaller companies willing to pay a higher commission for a quick infusion of capital.

The Canadian government called a halt to SRTCs in May 1985, after suspending parts of the programme in October 1984. Revenue Canada now has about 100 investigators performing audits on all tax returns claiming SRTCs, sending out teams of investigators when there is suspicion of fraud. Currently there are 58 companies under investigation. Revenue officials estimate that so far $\$ 220$ million has been recovered, but as much as $\$ 900$ million may have been lost forever. Analysts familiar with SRTCs reckon that the unrecoverable revenue may be much higher than the $\$ 900$ million the government acknowledges, perhaps as much as $\$ 3,000$ million. Supporters of the tax credit scheme nevertheless say the system could have been saved and abuses prevented with only slight modifications. By requiring SRTCs to be held for at least two years, schemes like the quick flip would have been impossible.

According to Guy Steed, associate director of research for the Canadian Science Council, the fallout from SRTCs has tarnished the national image of industrial research and development. Joseph Palca 